\title{
Strategi Komunikasi Pemasaran Harian Republika Untuk Menciptakan Kepuasan Pelanggan ( Studi kasus pada Harian Umum Republika )
}

\author{
Rini Dianti $\left.{ }^{*}\right)$ \\ email :fauzi_rini@yahoo.com
}

\begin{abstract}
ABSTRAK
Kehadiran media sosial pada saat ini membuat media cetak harus lebih kreatif lagi. Oleh karena itu diperlukan strategi komunikasi yang bisa memberikan kepuasan kepada pelanggannya untuk loyal kepada media cetak khususnya Republika sebagai media nasional.

Penelitian ini bertujuan untuk membahas strategi komunikasi pemasaran dan penerapan dari elemen-elemen komunikasi pemasaran terpadu, dengan obyek penelitian Harian Republika.

Guna mencapai pembahasan strategi tersebut, digunakan metode penelitian kasus dengan tehnik pengumpulan data : wawancara, observasi dan dokumentasi

Hasil Penelitian secara umum menunjukkan bahwa strategi komunikasi pemasaran Harian Republika masih menggunakan prinsip dasar elemen komunikasi pemasaran konvensional. Hal ini menunjukkan kesesuaian antara pola-pola konseptual teori yang relevan dengan pola-pola temuan studi kasus. Penggunaan strategi komunikasi pemasaran didasarkan kepada kebutuhan pelanggan. Dalam menjalankan strategi komunikasi pemasaran Harian Republika ada factor pendukung dan factor penghambat .

Pada kesimpulan, dalam mengelola media cetak seyogyanya terus melakukan inovasiinovasi baru dan kreatif dalam melakukan strategi komunikasi pemasaran agar bisa menyesuaikan dengan perkembangan jaman dan bisa memenuhi kebutuhan pelanggan.
\end{abstract}

Kata kunci : Media Cetak, Strategi Komunikasi Pemasaran, Kepuasan Pelanggan

\section{ABSTRACT}

Curently the presence of social media at this time to make the print media should be more creative. Therefore, communication strategy have to be developed intensively by media companies, satisfaction to its customer to loyal to print media especially Republika as national media.

The objective this research is to define the marketing communication strategy and implementation of elements of integrated marketing communications, with the object of research Republika Daily.

In order to achieve the goal research, case study method use data collection technique: interview, observation and documentation

Generally, the resultof research on Daily Republikaindicate that the marketing communication strategy using the conventional and basic marketing communication elements. This indicates the relation between the pattern of conceptual theory relevant to tje pattern of finding strategy based on customer needs. There are strenght and weakness factors in implementingstrategic marketing communication Daily Republika .

In conclusion, media company should be more innovative and creative in apply marketing communication strategis, in order to adapt and meet the customer needs.

Keywords: Print Media, Marketing Communication Strategy, Customer Satisfaction 


\section{A. Pendahuluan}

Media cetak merupakan media yang berpengaruh besar dalam sejarah kemerdekaan Indonesia. Pasca Indonesia merdeka, media cetak adalah sarana yang paling utama bagi masyarakat dalam mengemukakan pendapat. Walau demikian, kini eksistensi media cetak khususnya di Indonesia dipertanyakan. Akankah media massa cetak dapat bertahan di tengah arus perkembangan tekhnologi yang semakin canggih ini?

Melihat persaingan pasarnya, media cetak sebenarnya sedikit "kalah saing" dengan media massa lainnya seperti media Televisi maupun online. Kecanggihan tekhnologi keduanya mampu mempengaruhi masyarakat sehingga menjadi beralih mengkonsumsi media online di bandingkan dengan media cetak demi mendapatkan berita atau informasi yang cenderung cepat saji. Lambat laun jika terus seperti ini, media cetak bisa terancam mati. Sebenarnya sekarang ini media cetak sendiri sudah berada dalam ranah yang tidak menentu seperti "mati segan, hidup pun tak mau".

Namun demikian, bukan berarti bahwa hanya perkembangan teknologi saja yang menjadi harga mati atau ancaman terhadap perkembangan media cetak. Perkembangan media cetak, termasuk di dalamnya koran merupakan industri yang sangat menarik untuk dikaji, karena kemampuan dan daya saingnya sangat dipengaruhi oleh faktornya-faktornya, seperti tingkat harga dan segmentasi produk, struktur persaingan industri, isi , kualitas produk dan faktornya lainnya. Ada banyak hal yang sebenarnya juga turut menjadi penyebab berkembang atau tidaknya sebuah media cetak seperti, minat baca masyarakat yang minim, kurangnya pemasokan iklan, kepentingan para kapitalis dan para politisi, regulasi, sumber daya manusia, pajak kertas yang tinggi, persaingan diantara media cetak sendiri, idealis para kuli tinta dengan pemilik perusahaan, dan lain-lain. Pertanyaan yang sekarang perlu dipikirkan oleh media cetak adalah bagaimana cara bertahan hidup di tengah-tengah persaingan bisnis media ini?

Pada saat ini ada lima koran yang masuk dalam kategori koran nasional yaitu : Kompas, Republika, Media Indonesia, Koran Tempo dan Seputar Indonesia .Harian Republika sebagai media yang turut memeriahan dunia literasi di Indonesia memang harus diakui oleh masyarakat dengan terobosan-terobosannya. Berbagai inovasi dilakukan dan Harian Republika selalu berusaha menjadi harian yang selalu terdepan atau lebih dahulu melakukan langkah kreatif.

Konsep pemasaran merupakan kunci untuk menggapai tujuan organisasi secara lebih efekif dibandingkan kompetitor dengan menemukan kebutuhan dan keingina konsumen, serta menciptakan, menyampaikan, dan mengkomunikasikan sejumlah nilai (values) pada sasaran / konsumen terpilih yang berpotensi. Dengan kalimat 
sederhana, konsep pemasaran berangkat dari jargon "Know your targetmarket and satisfy them better than competitors", Republika berusaha untuk memberikan kepuasan yang terbaik dalam pelayanan dan jasa kepada pelanggannya.

Kepuasaan pelanggan merupakan hal yang sangat penting, karena itu diperlukan strategi komunikasi pemasaran yang tepat untuk dapat mencapai kepuasan tersebut.

\section{B. Perumusan Masalah}

Berpangkal dari latar belakang masalah seperti yang telah diuraikan diatas, Perumusan masalah sebagai berikut

1. Bagaimana strategi komunikasi pemasaran Harian Republika dalam menciptakan kepuasan kepada pelanggannya.

2. Bagaimana Republika memberikan kepuasaan pelanggannya.

3. Faktor-faktor apa saja yang menjadi pendorong strategi komunikasi pemasaran Harian Republika

4. Faktor-faktor apa saja yang menjadi penghambat strategi komunikasi pemasaran Harian Republika

\section{TujuanPenelitian}

Tujuan dari penelitian ini adalah :

1. Untuk mengetahui bagaimana strategi komunikasi pemasaran Harian Republika dalam menciptakan kepuasan kepada pelanggannya.

2. Untuk mengetahui bagaimana Republika memberikan kepuasaan pelanggannya.

3. Untuk mengetahui faktor-faktor apa saja yang menjadi pendorong strategi komunikasi pemasaran Harian Republika

4. Untuk mengetahui faktor-faktor apa saja yang menjadi penghambat strategi komunikasi pemasaran Harian Republika

\section{Landasan Teori}

Strategi komunikasi pemasaran menurut Hifni Alifahmi (2005; 101-106) adalah perencanaan secara cermat mengenai kegiatan pemasaran sebagai usaha untuk menyampaikan pesan kepada publik terutama konsumen sasarannya mengenai keberadaan produk di pasar agar tercapai tujuan yang diinginkan . 
Gambar 1

\section{SEGITIGA EMAS STRATEGIC MARKETING COMMUNICATIONS}

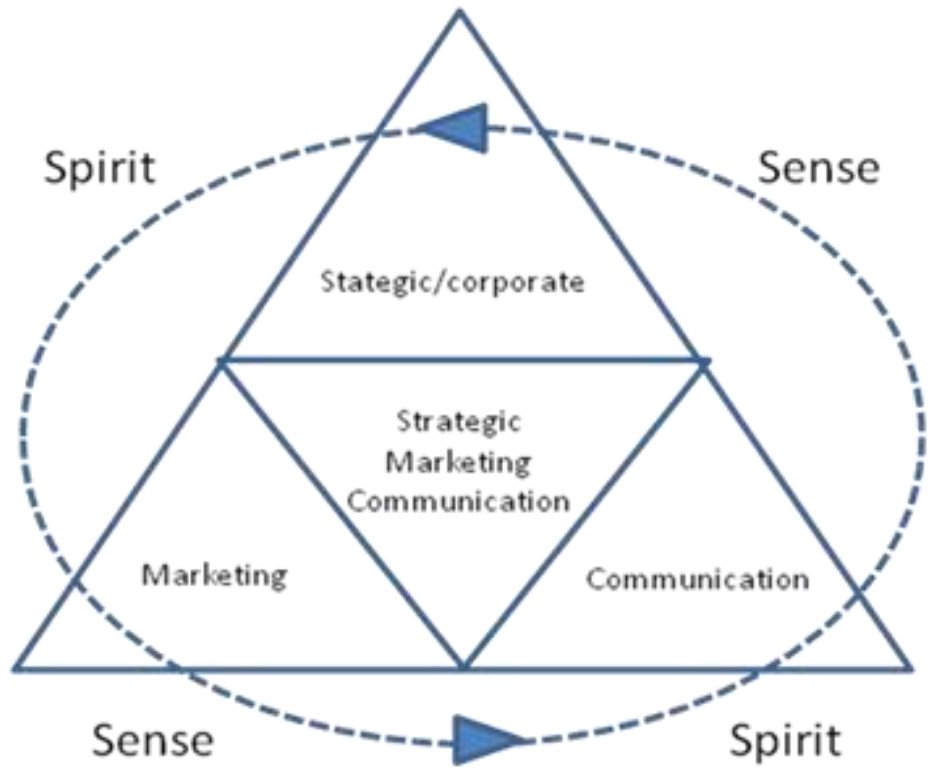

Sumber:

Hifni Alif ahmi, Marketing Commuinications Orchestra, p xxi

Strategi komunikasi pemasaran bertujuan agar konsumen yang menjadi sasaran penjualan mengetahui bahwa produk mereka ada di pasaran. Suatu strategi komunikasi pemasaran dapat dikatakan berhasil apabila pesan yang disampaikan dapat dipahami oleh khalayak sasaran dan membuat khalayak sasaran melakukan sesuatu sesuai dengan isi pesan yang disampaikan.

Berdasarkan analisa-analisa sumber daya yang dimiliki oleh perusahaan dan penarikan kesempatan-kesempatan pasar, suatu strategi berada dalam posisi untuk menetapkan tujuan-tujuan operasional yang realistik bagi perusahaan yang tergambar dalam model sebagai berikut 
Gambar 2

Gambar Strategi Komunikasi Pemasaran

\section{Misi Korporasi \\ Tujuan Korporasi \\ Strategi Korporasi}

Tujuan Pemasaran

Strategi Pemasaran

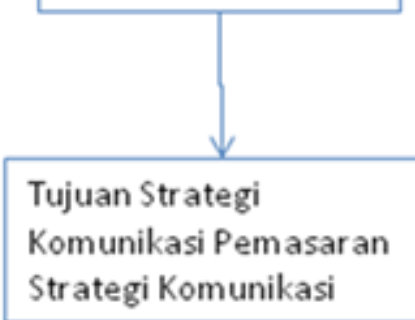

Sumber:

P.R Smith (1993). Marketing Communication: An Integrated Approach,

London:Kogan Page Limited, p. 32

Strategi komunikai pemasaran harus sejalan denan strategi pemasaran dan strategi perusahaan. Hasil analisis pemasaran, perencanaan dan kontrol terhadap faktor-faktor yang menyangkut produk, harga, tempat dan promosi merupakan dasar bagi penjabaran strategi komunikasi pemasaran yang akan dilakukan (Chris Fill, 1995:5)

\section{Gambar3}

TAHAPPENCAPAIAN TUJUAN KOMUNIKASI DAN STRATEGIKOMUNIKASI

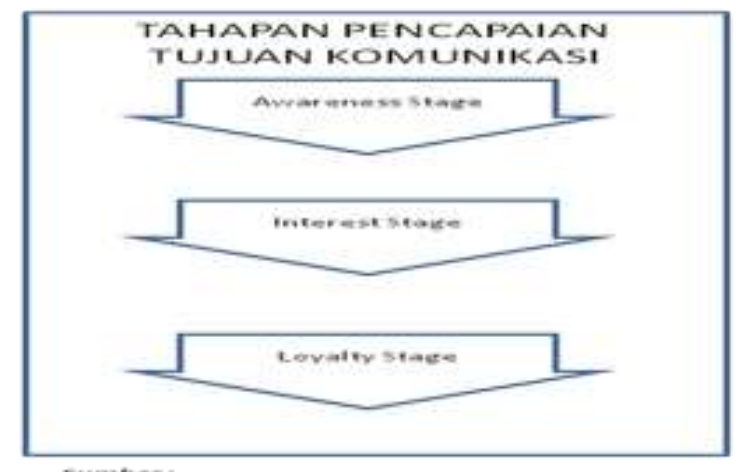

STRATEGIKOMUNIKASI

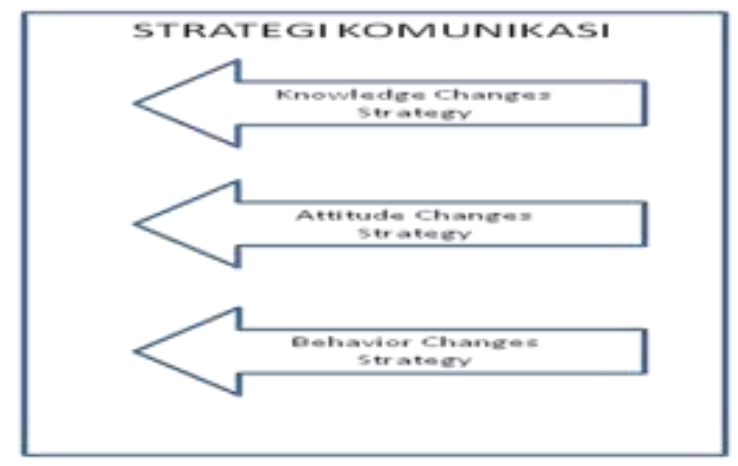

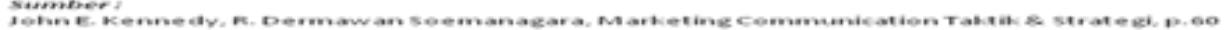


Menurut Zeithaml dan Bitner (2000:75) definisi kepuasan adalah : Respon atau tanggapan konsumen mengenai pemenuhan kebutuhan. Kepuasan merupakan penilaian mengenai ciri atau keistimewaan produk atau jasa, atau produk itu sendiri, yang menyediakan tingkat kesenangan konsumen berkaitan dengan pemenuhan kebutuhan konsumsi konsumen.

Kepuasan konsumen dapat diciptakan melalui kualitas, pelayanan dan nilai.

1.Kualitas, mempunyai hubungan yang erat dengan kepuasan konsumen. Kualitas akan mendorong konsumen untuk menjalin hubungan yang erat dengan perusahaan. Dalam jangka panjang, ikatan ini memungkinkan perusahaan untuk memahami harapan dan kebutuhan konsumen. Kepuasan konsumen pada akhirnya akan menciptakan loyalitas konsumen kepada perusahaan yang memberikan kualitas yang memuaskan mereka.

2. Pelayanan konsumen, tidak hanya sekedar menjawab pertanyaan dan keluhan konsumen mengenai suatu produk atau jasa yang tidak memuaskan mereka, namun lebih dari pemecahan yang timbul setelah pembelian.

3. Menurut Kotler (2000:34) definisi nilai pelanggan adalah :Nilai yang dirasakan pelanggan adalah selisih antara jumlah nilai pelanggan dengan jumlah biaya pelanggan.Jumlah nilai pelanggan adalah sekelompok manfaat yang diharapkan dari produk dan jasa. Jumlah biaya pelanggan adalah sekelompok biaya yang digunakan dalam menilai, mendapatkan, menggunakan dan membuang produk atau jasa.

Menurut Zeithaml et.all, terdapat empat faktor yang mempengaruhi persepsi dan ekspektasi pelanggan,yaitu sebagai berikut :

1. Apa yang didengar pelanggan dari pelanggan lainnya (word of mounth communication).Dimana hal ini merupakan faktor potensial yang menentukan ekspektasi pelanggan.Sebagai contoh, seorang pelanggan memiliki perusahaan yang di harapkan dapat memberikan pelayanan dengan kualitas tinggi berdasarkan rekomendasi teman-teman atau tetangganya.

2. Ekspektasi pelanggan sangat bergantung dari karakteristik individu dimana kebutuhanpribadi (personnel needs).

3. Pengalaman masa lalu (past experience) dalam menggunakan pelayanan dapat juga mempengaruhi tingkat ekspetasi pelanggan.

4. Komunikasi dengan pihak eksternal (external communication) dari pemberi layanan memainkan peranan kunci dalam membentuk ekspektasi pelanggan.Berdasarkan External communication,perusahan pemberi layanan dapat memberikan pesan-pesan secara langsung maupun tidak langsung kepada pelanggannya.Sebagai contoh dari pengaruh adanya external communication adalah harga di mana biaya pelayanan sangat berperan penting dalam membentuk ekspektasi pelanggan. 
Dengan demikian, kemungkinan antara ekspektasi pelanggan dan kualitas pelayanan (jasa) yang di terimanya, adalah sebagai berikut :

1. Pelanggan menjadi senang jika kualitas pelayanan yang diterima lebih baik dari perkiraannya.

2. Pelanggan menjadi biasa saja jika kualitas pelayanan yang terima sama dengan perkiraannya.

3. Pelanggan menjadi kecewa jika kualitas pelayanan yang diterima lebih jelek dari perkiraannya

Dari definisi diatas bahwa kepuasan pelanggan merupakan fungsi dari kesan kinerja dan harapan. Jika kinerja berada dibawah harapan maka pelanggan tidak puas. Jika kinerja memenuhi harapan, maka pelanggan akan puas. Jika kinerja berada diatas harapan maka pelanggan akan puas. Jika kinerja berada diatas harapan maka pelanggan merasa amat puas dan senang. Banyak perusahaan yang berfokus pada kepuasaan yang tertinggi oleh karena para pelanggan yang hanya merasa puas mudah untuk berubah pikiran bila mendapat penawaran yang lebih baik. Sedangkan pelanggan yang amat puas lebih sukar untuk berubah pilihannya. Dalam hal ini kepuasan yang tinggi dan kesenangan akan menciptakan kelekatan emosional terhadap merek, bukan hanya preferensi rasional saja.

Dengan demikian hasilnya adalah kesetiaan pelanggan yang tinggi terhadap produk tersebut. Kepuasan pelanggan merupakan kunci dalam menciptakan loyalitas pelanggan .

Marketing communication merupakan bentuk komunikasi yang bertujuan untuk memperkuat strategi pemasaran, guna meraih segmentasi yang lebih luas, atau dapat juga dikatakan sebagai upaya untuk memperkuat loyalitas pelanggan terhadap produk, yaitu barang dan jasa yang dimiliki perusahaan. Dalam menetapkan strategi komunikasi pemasaran Republika untuk menciptakan kepuasan pelanggannya maka , komunikasi pemasaran terpadu atau IMC menjadi hal yang harus diperhatikan, disamping itu juga faktor-faktor pendorong dan faktor-faktor penghambat dari strategi komunikasi pemasaran juga harus menjadi perhatian penting.

Marketing communication merupakan bentuk komunikasi yang bertujuan untuk memperkuat strategi pemasaran, guna meraih segmentasi yang lebih luas, atau dapat juga dikatakan sebagai upaya untuk memperkuat loyalitas pelanggan terhadap produk, yaitu barang dan jasa yang dimiliki perusahaan. Dalam menetapkan strategi komunikasi pemasaran Republika untuk menciptakan kepuasan pelanggannya maka , komunikasi pemasaran terpadu atau IMC menjadi hal yang harus diperhatikan, disamping itu juga faktor-faktor pendorong dan faktor-faktor penghambat dari strategi komunikasi pemasaran juga harus menjadi perhatian penting.

Berdasarkan judul penelitian, maka kerangka pemikiran dalam penelitian ini adalah sebagai berikut : 
Gambar 4

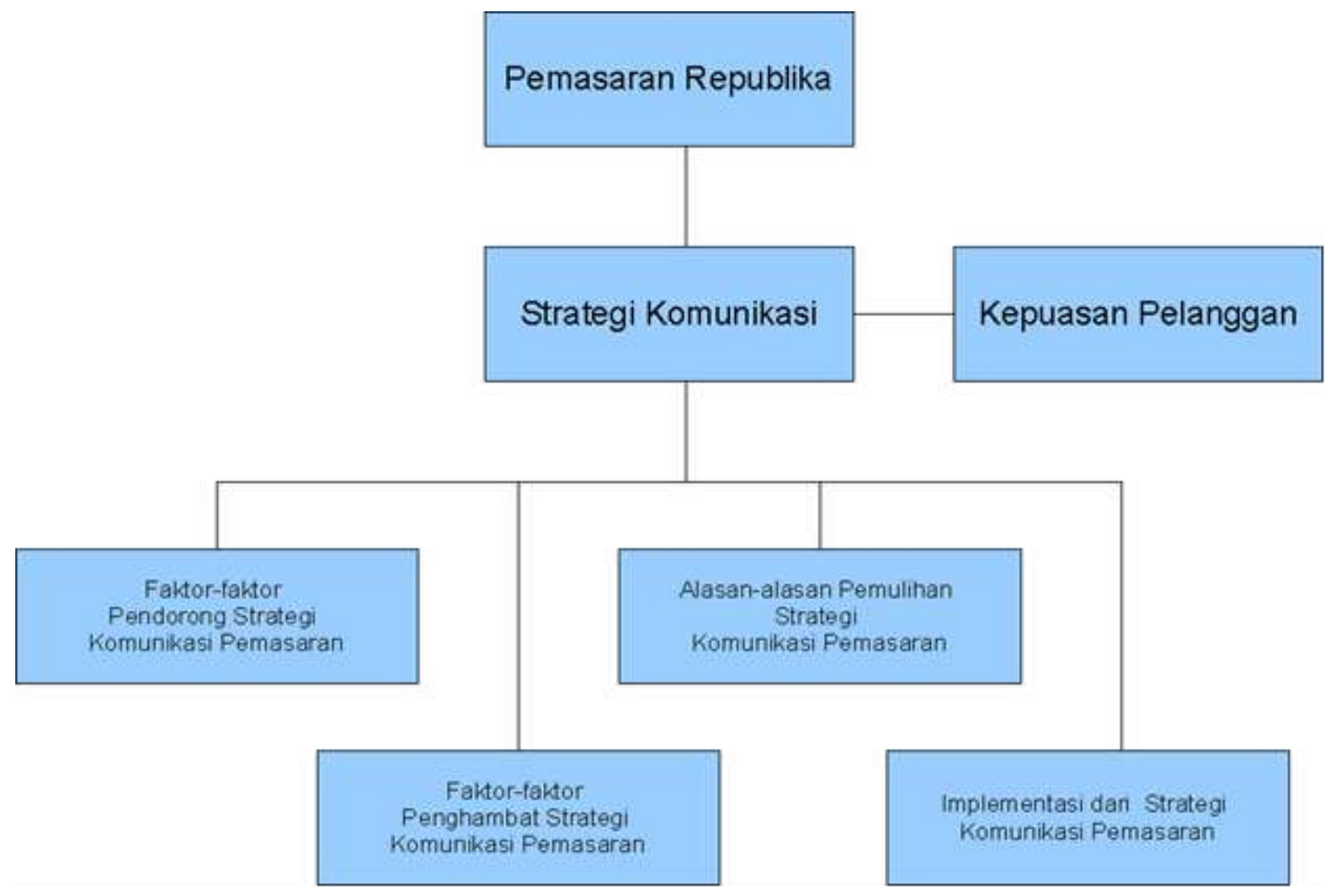

\section{E. Metode Penelitian}

Metode penelitian yang digunakan dalam penelitian ini adalah Studi Kasus . Menurut M. Hariwijaya dalam Metodologi dan Tehnik Penulisan Skripsi, Tesis dan Disertasi ( 2007:74), studi kasus adalah metode penelitian yang menggunakan berbagai sumber data (sebanyak mungkin data) yang bisa digunakan untuk meneliti, menguraikan dan menjelaskan secara komprehensif berbagai aspek individu, kelompok, suatu program, organisasi atau peristiwa secara sistematis. Penelahaan berbagai sumber data ini membutuhkan berbagai macam instrument pengumpulan data. Karena itu peneliti dapat menggunakan wawancara mendalam, observasi partisipan. Dokumentasi-dokumentasi, kuesioner ( hasil survey ) rekaman, bukti-buki fisik, dan lainnya.

Yang akan dicapai dalam penelitian ini adalah penjelasan tentang bagaimana strategi komunikasi pemasaran yang dilakukan Harian Republika untuk menciptakan kepuasan pelanggan. Hal ini dilakukan dengan cara mencati tahu faktor-faktor pendorong dan faktor-faktor penghambat dari Strategi Komunikasi Pemasaran yang dilakukan Harian Republika dalam menciptakan Kepuasan Pelanggan. 


\section{F. Hasil \& Pembahasan}

Dalam penelitian ini, penulis mencari informasi tentang aktivitas komunikasi pemasaran Republika dari berbagai sumber dan pihak-pihak yang dianggap kompeten baik dari narasumber internal terstruktur maupun pihak lain yang pernah atau masih berkecimpung dengan aktivitas Republika. Informan tersebut dipilih peneliti karena diyakini memiliki kredibilitas untuk dapat memberikan informasi yang memadai kepada peneliti.

Strategi Komunikasi yang dilakukan Republika. Sesuai dengan ruh nya bahwa Harian Republika adalah koran Yang bernafaskan Islam , dan ini merupakan kekuatan dari Republika. Dan menjadi koran yang Rahmatan Lil Alamin bagi umat. Langkah pertama untuk mengetahui tujuan dari komunikasi pemasaran yang dilakukan oleh Republika adalah :

Komunikasi pemasaran Republika bertujuan untuk meningkatkan brand awareness Republika terutama terkait dengan perubahan yang dilakukan Republika dengan adanya multiplatform. Sehingga pembaca maupun pemasang iklan bisa menikmati Republika dari platform yang berlainan juga untuk pemasang iklan mau bekerjasama untuk mempromosikan atau menginformasikan produk maupun programnya kepada pembaca yang menggunakan Republika multiplatform tersebut.(Yulianingsih Yamin GM Marketing Republika wawancara 04/10/2015)

Tantangan ke depan dengan banyaknya industri media sosial yang sangat digandrungi masyarakat, bagaimana dengan strategi komunikasi yang dilakukan oleh Republika:

Seiring dengan perkembangan dan kemajuan dunia teknologi pada saat ini , Republika di usia yang 20 tahun ini melakukan pengembangan jaringan media atau multiplatform . Dimana Republika mencoba masuk ke seluruh usia melalui koran Republika, Alif TV, Penerbit Republika, Republika Online, Janna magazine dan juga RepMagz yang bisa diakses dari Ipad. (Yulianingsih Yamin- GM Marketing Republika wawancara 04/10/2015)

\section{Bagaimana strategi komunikasi pemasaran yang dilakukan oleh bagian iklan Republika?}

Strategi pemasaran yang dilakukan bagian iklan dalam menjual produknya melalui penjualan langsung ke klien (direct selling), penjualan tidak langsung (agency/pihak ketiga lainnya), promosi dan support pemberitaan. Strategi tersebut cukup efektif dalam mengaet klien (pembeli). Klien yang tadinya tidak beriklan kemudian mengambil keputusan beriklan setelah kita memberikan support pemberitaan yang 
cukup. Sehingga adakalanya pola penjualan langsung masih harus didukung dengan pemberitaan, karena pada kenyataannya klien tidak semata-mata membutuhkan diskon atau cashback saja tapi juga liputan tentang dirinya atau kiprah perusahaannya. (Indra Wisnu Wardhana - Manajer Iklan Republika wawancara 01/11/2015)

Republika sepertinya masih optimis untuk tetap bertahan karena dengan kekuatan $81 \%$ pembaca Republika adalah pelanggan dan juga pembaca serta pelanggan loyal dari Republika yang masih terus bertahan sampai saat ini.

\section{Upaya Republika agar semakin dipercaya pelanggan}

Pelanggan dan pembaca adalah unsur pokok dari media cetak untuk tetap bisa bertahan dan tetap eksis. Upaya apa yang dilakukan Republika agar semakin dipercaya pelanggan.

Adapun upaya-upaya yang dilakukan oleh Republika untuk menciptakan kepuasan kepada pelanggannya adalah memberikan berita-berita yang akurat atau trust kepada pembaca demi kepentingan umat. Dan juga kegiatan-kegiatan off air yang dilakukan agar lebih dekat dengan pembaca.((Yulianingsih Yamin- GM Marketing Republika, wawancara 04/10/2015)

Memberikan nilai lebih dan previllege bagi pelanggan untuk tetap terus bertahan dan melibatkan pelanggan dalam kegiatan yang dilakukan oleh Republika adalah upaya untuk menciptakan kepuasan kepada pelanggan.

Mengadakan kegiatan-kegiatan dan aktivasi-aktivasi yang menjadi jembatan Republika dengan Pembacanya, yaitu : Republika Ramadhan Fair, Jalan-jalan Abah Alwi, Kelompok membaca Al-qur'an, Republika Card yang bekerjasama dengan merchant-merchant lainnya untuk memberikan diskon bagi pelanggan Republika, CSR Bagimu guru kupersembahkan, Dzikir Nasional, kewirausahaan BRI entrepreneurship.((Yulianingsih Yamin- GM Marketing Republika, wawancara 04/10/2015)

\section{Sejauh ini apakah yang menjadi faktor pendorong dari strategi komunikasi yang dijalankan oleh Republika?}

Faktor pendorongnya adalah support dari manajemen untuk melakukan semua pemasaran, baik dari moril maupun materiil. Selain itu motivasi yang kuat dari seluruh staf dan karyawan Republika untuk mengambil peluang yang besar dari perubahan media saat ini. Sehingga insya Allah Republika akan semakin jaya dan sukses.((Yulianingsih Yamin - GM Marketing Republika, wawancara 04/10/2015) 


\section{Apa Program unggulan Republika?}

Program Cahaya Ramadhan, Idul Fitri dan juga suplemen Haji ini masih menjadi program ungulan Republika . Dengan program unggalan ini maka setiap tahunnya mengalami peningkatan pendapatan dan juga jumlah pembaca Republika $100 \%$ dari titik terendah dan ini sudah dapat dirasakan dari lima tahun terakhir ( 2007 2012)((Yulianingsih Yamin - GM Marketing Republika wawancara 04/10/2015)

Berangkat darri kehadiran Republika adalah untuk menyampaikan aspirasi ummat , maka Republika adalah Koran nasional yang bernafaskan Islam, sehingga untuk program-program unggulan nya adalah : Program Cahaya Ramadhan, Idul Fitri dan juga suplemen Haji . Dengan program ungglan ini maka setiap tahunnya mengalami peningkatan pendapatan dan juga jumlah pembaca Republika 100\% dari titik terendah dan ini sudah dapat dirasakan dari lima tahun terakhir.

\section{Sejauh ini apakah yang menjadi faktor penghambat dari strategi komunikasi yang dijalankan oleh Republika?}

Faktor yang menghambat atau yang menjadi tantangan adalah bagaimana menyesuaikan dengan persaingan yang ada diluar. Persaingan yang seringkali tidak sehat sehingga kita harus menyusun strategi untuk memenangkan persaingan tersebut.((Yulianingsih Yamin- GM Marketing Republika wawancara 04/10/2015)

Kemunculan media massa online bukan jadi suatu ancaman bagi media cetak dan media elektronik serta tidak menggangap adanya sebuah persaingan, karena masingmasing media massa mempunyai kelebihan dan kekurangan serta memiliki para peminatnya masing-masing dan justru menjadi ragam pilihan dalam mendapatkan berita dan informasi.

\section{Bagaimana dengan pesaing Republika?}

Pesaing Republika sebagai koran Nasional adalah Kompas,Sindo,media Indonesia dan Koran Tempo.((Yulianingsih Yamin, wawancara 04/10/2015)

Semakin banyak pebisnis yang muncul maka persaingan pun akan semakin ketat sehingga memaksa para pelaku bisnis untuk menciptakan strategi pemasaran baru dan efektif dalam memenangkan persaingan yang ada

\section{Bagaimana dengan perkembangan pelanggan Republika dalam 5 tahun terakhir ini}

Perkembangan Republika dalam lima tahun terakhir secara prosentase memang ada pertumbuhan (untuk angka tidak bisa saya sebutkan). Namun diakui pertumbuhan yang terjadi tidak sebesar yang direncanakan. Hal ini terkait dengan 
perkembangan teknologi dimana, kelompok muda lebih menyukai membaca informasi melalui smartphone atau gadget.(Indra Wisnu Wardhana - Manajer Iklan Republika, wawancara 01/11/2015)

Oleh karena itu hal yang paling penting untuk terus dibinadan dipertahankan adalah bagaimana meningkatkan kualitas hubungan denan pelanggan.

Komunikasi Pemasaran Terpadu ( Integrated Marketing Communication - IMC

Dengan kata lain dapat dikatakan bahwa komunikasi pemasaran memegang peranan yang sangat penting bagi pemasar. Keberadaan komunikasi merupakan hal yang mutlak. Konsekuensinya tanpa komunikasi, maka pelanggan, konsumen maupun masyarakat umum tidak akan mengetahui suatu produk yang dihasilkan suatu perusahaan.

\section{Apakah pendekatan Integrated Marketing Communication ( IMC) dapat membantu strategi yang dijalankan?}

lya kami melakukan yang namanya bundling kovergensi dimana, ketika kami melakukan penawaran ataupun presentasi kepada pelanggan maka kami akan memberikan beberapa alternatif sehingga pelanggan ( pemasang iklan ) akan bisa menggunakan jaringan dari media Republika group , sebagai contoh paket dengan Telkomsel maka selain telkomsel dapat beriklan di Koran Republika, majalah Janna, kemudian di Republika online, dan kemudian juga punya kanal di Jurnal haji Republika selama musim haji. Dengan multiplatform Republika group maka kami akan maksimal memberikan yang terbaik untuk pelanggan ( pemasang iklan Republika). ((Yulianingsih Yamin - GM Marketing Republika, wawancara 04/10/2015)

Integrated marketing communication (IMC) mengarah pada total strategi komunikasi pemasaran yang bertujuan membangun hubungan pelanggan yang kuat dengan menunjukkan bagaimana perusahaan dan produk yang dapat membantu pelanggan memecahkan masalah.

Meningkatnya intensitas persaingan dan jumlah pesaing menuntut setiap perusahaan untuk selalu memperhatikan kebutuhan dan keinginan konsumen serta berusaha memenuhi apa yang mereka harapkan dengan cara memuaskan pelanggan daripada yang dapat dilakukan pesaing. Banyaknya tawaran atau pilihan dari banyak perusahaan telah membentuk kondisi masyarakat yang semakin kritis dalam memilih produk mana yang paling memberi kepuasan baginya.

Kepuasan pelanggan dapat menciptakan kesetiaan atau loyalitas pelanggan kepada perusahaan yang memberikan pelayanan dan kualitas yang memuaskan. Pelanggan yang telah mencapai kepuasan sangat memungkinkan sekali untuk 
memberitahukan kepada teman, rekan maupun orang lain akan pengalaman yang mereka

Dengan bertambahnya usia Republika yang pada saat ini dan banyaknya inonasiinovasi yang sudah dijalankan , apa harapan Republika ke depan nantinya.

Ke depannya dengan adanya multiplatform Republika group ini saya berharap, ini bisa memperluas reach pembaca Republika sehingga bisa diterima oleh semua kalangan dewasa- anak muda- yang masih konvensional yaitu orang-orang yang masih membaca koran, majalah maupun dengan media social yang ada karena saat ini sudah ada RepublikaMag yang bisa di buka melalui Ipad. Dengan multiplatform ,berharap bisa memperluas jangkauan Republika. Dan Republika bisa dinikmati oleh semua segmen usia, pria dan wanita dimanapun mereka berada.((Yulianingsih Yamin - GM Marketing Republika, wawancara 04/10/2015)

Adapun multiplatform Republika adalah sebagai berikut :

- Republika Penerbit - PT. Pustaka Abdi Bangsa

Republika penerbit lahir tahun 2002, dari sebuah divisi penerbit buku surat kabar ternama Harian Republika, Ialu menjadi perusahaan penerbit di bulan Juli 2003, dengan nama PT. Pustaka Abdi Bangsa. Petama kali menerbitkan buku berjudul Panduan Puasa, karya Quraish Shihab, kemudian Ayat-Ayat Cinta ( Habiburrahman El-Sirazy), sebuah novel yang behasil meraih penghargaan

sebagai Novel Fiksi Dewasa terbaik tahun 2006, dan telah difilemkan menjadi Mega Best Seller yang fenomenal di Indonesia.Menyusul selanjutnya Ketika Cinta Bertasbih ( Habiburrahman El-Sirazy), Hafalan Shalat Delisa ( Tere Liye), dan banyak lainnya. Semua buku Republika penerbit dapat diperoleh dengan mudah di hampir seluruh pelosok Indonesia yang penjualannya dilakukan lewat toko buku besar di seluruh Indonesia dan juga Agen buku di Jakarta dan di daerah. Selain itu juga ikut serta dalam pameran-pameran buku besar di Indonesia.

- $\quad$ Alif Tv - Pemberi Insipirasi

Republika Media Visual adalah unit usaha MAHAKA MEDIA dan bagian langsung dari Republika Group yang berkonsentrasi pada penyediaan Audio-Visual kontent seputar gaya hidup islami. Pemilihan konten islami salah satunya dikarenakan masih terbukanya peluang dan adanya kebuuhan dari masyarakat Indonesia yang mayoritas beragama Islam dan juga sebagai kepanjang tangan dari induk Republika Media Visual ( RMV) yakni Republika yang juga lebih terkonsentrasi di konten-konten bernuansa islami.

- Republika On Line 
Penerapan IMC secara bersama-sama atau terpadu akan semakin memperkuat pasar dan jaringan pelanggan sehingga dalam jangka waktu tertentu juga dapat meningkatkan omzet penjualan perusahaan. Integrated Marketing Communcation(IMC ) sangat membantu dalam strategi komunikasi yang dilakukan oleh Republika, dalam hal ini Republika sering melakukannya dengan membuat paket bundling dengan unit-unit usaha lainyang tergabung dalam multiplatform. Ini sudah dilakukan Republika dengan Telkomsel dimana iklan-iklan dari Telkomsel dipasang di koran Republika dan juga group Republika baik iklan komersil ataupun advertorial dimana pemasangannya disesuaikan dengan tematik dari Telkomsel. Selain itu juga Republika Online dalam Jurnal haji Telkomsel. Demikian juga halnya dengan kerjsama paket yang dilakukan dengan Bank Syariah Mandiri, Bank Muamalat, BRI, BNI dan Bank Mandiri.

Perusahaan yang menghasilkan produk, baik itu berupa barang atau jasa harus melakukan kegiatan pemasaran, tujuannya agar produk tersebut dapat dikonsumsi oleh konsumen. Semua organisasi baik perusahaan bisnis maupun nirlaba mengunakan berbagai bentuk komunikasi pemasaran untuk mempromosikan apa yang meraka tawarkan dan mencapai tujuan finansial dan non finasial. Dan Republika menggunakan bentuk komunikasi pemasarannya dengan IMC ini.

\section{G. Kesimpulan}

Kepuasan Konsumen merupakan komponen penting untuk membantu keberhasilan strategi yang diambil perusahaan. Kepuasan Konsumen dapat menjelaskan mengapa pelanggan lebih memilih produk atau jasa yang ditawarkan oleh suatu perusahaan daripada perusahaan pesaing karena Kepuasan Konsumen merefleksikan pemikiran pelanggan terhadap perusahaan, baik itu merupakanpenilaian mereka sendiri terhadap perusahaan secara keseluruhan maupun didapat dari membandingkan dengan perusahaan pesaing. Perusahaan tidak dapat mengabaikan lingkungan bisnis perusahaan sebagai faktor eksternal yang dapat mempengaruhi kinerja perusahaan. Lingkungan bisnis merupakan elemen penting penyebab yang signifikan dalam penentuan strategi operasi perusahaan yang akan berdampak langsung terhadap kinerja perusahaan. . Hasil yang didapatkan ternyata memang dengan kepuasan konsumen yang baik maka akan meningkatkan kinerja perusahaan. Dengan memperhatikan faktor ekternal yaitu lingkungan, yang telah terbukti mempengaruhi secara langsung kinerja perusahaan.

Menciptakan dan meningkatkan kualitas layanan bagi pelanggan akan mempengaruhi secara positif pada kepuasan pelanggan. Pelanggan yang merasa puas akan melanjutkan bisnisnya dengan perusahaan tersebut, serta akan memberikan rekomendasi kepada pelanggan lainnya agar melakukan apa yang 
seperti dilakukannya. Pelanggan akan loyal kepada perusahaan yang memberikan kualitas layanan yang baik bagi mereka. Begitu juga bagi perusahaan, bahwa pelanggan yang loyal akan memberikan nilai yang tinggi terhadap perusahaan.

1. Penggunaan strategi komunikasi pemasaran didasarkan kepada kebutuhan pelanggan dan calon pelanggan. oleh karena itu, perlu adanya riset untuk mengetahui keinginan pasar sehingga mampu menyusun merode pemasaran yang tepat dan efektif.

2. Adanya hubungan yang lebih erat antara perusahaan melalui produk, program dan kegiatam off air dengan para pelanggan

3. Republika masih menjadi referensi bagi pembaca, khususnya mengenai hal-hal yang terkait mengenai ke-Islaman

\section{H. Daftar Pustaka}

Alifahmi, Hifni, Sinergi Komunikasi Pemasran, Integrasi iklan, Public Relations dan Promosi, Sygmacorp, Jakarta, 2005

Kennedy, E. Jhon. R. Dermawan Soemanegara, Marketing Communication, PT Bhuana IImu Populer, Jakarta 2006

Kotler, Philip, "Manajemen Pemasaran", Edisi 13. Erlangga. Jakarta, 2009.

Masha Nasihin, Cerita di Balik Berita, Harian Umum Repiblika, Jakarta : 2010

Morissan, Periklanan dan Komunikasi Pemasran Terpadu, Ramdina Prakarsa, Tangerang, 2007

Punto , Anif Utomo, 17 tahun Republika, Penerbit Republika, Jakarta 2010

Tjiptono, Fandy, Strategy Pemasaran, Edisi kedua, Penerbit Andi, Yogyakarta , 2000

Zeithmal, VA. Bitner MJ, 2000, Conceptual Model Service Quality, Journal of Marketing Volume 49, Fall , pp. 12-20

Zeithmal, VA. Bitner MJ, 2000, Understanding Customer Expectations and Perception through Marketing Research, Integrating Costumer Focus Across The Firm. Service Marketing , 2nd Ed, Irwin McGraw-Hill, pp.107-136. 